\title{
The Straits of Malacca and Singapore: Maritime Conduits of Global Importance
}

\author{
Mohd Hazmi Bin Mohd Rusli ${ }^{1}$, Ade Maman Suherman ${ }^{2}$, Aryuni Yuliantiningsih ${ }^{2}$, Wismaningsih ${ }^{2} \&$ Noer Indriati $^{2}$ \\ ${ }^{1}$ Faculty of Syariah and Law, Universiti Sains Islam Malaysia, Malaysia \\ ${ }^{2}$ Faculty of Law, Universitas Jenderal Soedirman (UNSOED), Purwokerto, Indonesia \\ Correspondence: Mohd Hazmi Bin Mohd Rusli, Associate Professor, Faculty of Syariah and Law, Universiti Sains \\ Islam Malaysia, Malaysia.
}

Received: November 19, 2020

Accepted: January 4, 2021

Online Published: January 17, 2021

doi:10.5430/rwe.v12n2p123

URL: https://doi.org/10.5430/rwe.v12n2p123

\begin{abstract}
The Straits of Malacca and Singapore are two of the world's most crucial maritime highways. Srivijaya and the Malacca Sultanate were among the regional formidable political entities that were successful in exerting their power and influence over the Straits. The pre-eminence of the local kingdoms were overshadowed by the arrival of the European imperialists as early as the $16^{\text {th }}$ century, that changed the political dynamics in the region. The Straits of Malacca and Singapore remain important till today as it provides the shortest route linking petroleum producing-nations of West Asia and the oil consumers of East Asia. As such, the significance of the Straits of Malacca and Singapore global fulcrum of maritime trade is indisputable. Nevertheless, despite being the caretaker of these important Straits, Malaysia and Indonesia have a long way to go before they could be regarded as influential maritime States. This article concludes that both Malaysia and Indonesia should develop its oceans policy to go hand in hand with the global significance of the Straits of Malacca and Singapore. This has to be done in ensuring that both Malaysia and Indonesia could relive the glorious moments once enjoyed by both its predecessors - Srivijaya and Malacca.
\end{abstract}

Keywords: international trade, maritime history, straits of Malacca and Singapore, maritime nation, environment

\section{Introduction}

The Strait of Malacca begins between the north-western tip of the Indonesian island of Sumatra and the southern tip of Phuket, Thailand (Zulkifli et al., 2020). It divides the Malay Peninsula and Sumatra, subsequently joining the Strait of Singapore as it funnels down to the south (Ibrahim, Husin and Sivaguru, 2008). Both the Straits of Malacca and Singapore links the Indian to the Pacific Oceans via the South China Sea (Leifer, 1978). Together, the Straits of Malacca and Singapore have been significant for international maritime trade and its pre-eminence is unrivalled particularly in this part of the world (George, 2008).

The maritime civilisation of the Malay World has always been influenced by the Straits of Malacca and Singapore (M. H. M. Rusli, 2012). As such, the Strait of Malacca was initially described as 'the Malay Seas' as reported in a ninth century Arabic document, indicating Malay influence in the region (Andaya, 2008). The importances of these Straits have shaped the maritime history of this region with imperialistic quests for territorial annexation, economic domination and empire-building, both by the native and European colonial powers.

These three littoral States are caretakers of two of the most important maritime conduits in the world and remain as catalyst in realising the visions of both Malaysia and Indonesia to become leading maritime nations, particularly in the Asia-Pacific region.

\section{Early Port Kingdoms}

Port-kingdoms have fluorished and vanquished along the coast of the Strait of Malacca since the third century AD (Manguin, 2004). Some of these kingdoms became great maritime empires dominating the Strait of Malacca for hundreds of years. The native Malays actively engaged in trade and commerce as early as the third century AD through the kingdom of Langkasuka with foreign merchants from China, India and Persia calling at their ports (Dougald J.W. O'Reilly, 2007). The Kingdom of Old Kedah, too, was once a prosperous transit port for vessels waiting for the change of monsoonal winds, before embarking on their journey again sailing to the East (Pearn, 1965). 


\subsection{Kingdom of Srivijaya}

The mighty Malay Kingdom of Srivijaya emerged in the seventh century AD and consolidated its power to take control over the Strait of Malacca and the Strait of Sunda. Playing its role as the 'Master of the Strait of Malacca', the rulers of Srivijaya ruled the Malay World from their capital city of Palembang in Sumatra and participated actively in exploiting maritime trade flowing through the Strait (Lockard, 2009).

Srivijaya's role in Southeast Asian history as regional entrepot arose from the nautical skills of the Malays to exploit conditions of geography in developing maritime trading networks (Tarling, 1992).

\subsection{Sultanate of Malacca}

Malacca replaced Srivijaya in controlling the flow of trade via the Strait of Malacca in the fifteenth century. The Malacca Sultanate gradually rose into a regional power of considerable influence within a time span of a hundred years. This maritime kingdom left an everlasting legacy to the region, so much so that the name of this once dominant Sultanate is immortalised in the Strait that forms a maritime conduit that is crucial in maritime trade and transportation. Malacca developed not only into a prosperous international port, but also a formidable regional maritime empire (Buyers, 2008). It replaced Srivijaya and became the new 'Master of the Strait of Malacca' in the fiftenth century (Tarling, 1992).

Malacca enjoyed its glorious moments for slightly more than a century as a crucial entrepot in global maritime trading network (Lockard, 2009). Malacca at that time was reported to have a population of around 100,000, at par with other European cities at that time such as Naples and Paris, a bustling cosmopolitan city. The wealth of Malacca was envied by many of its rivals, and has attracted far-flung maritime powers to dominate it.

\section{Colonial Era}

The arrival of the Portuguese into this region has not only altered the fate of the once prosperous sultanate, but also the political dynamics and trade in the region (Harrison, 1966). The Portuguese arrived in 1511, followed by the Dutch in 1641 and finally the British in the eighteenth century.

\subsection{The Portuguese}

The Portuguese was the first European imperialist to set foot in Southeast Asia. The Portuguese subsequently sacked the sultanate and erected a strong foothold in the Malay Archipelago (Williams, 1976). The fall of the Malacca Sultanate did not in any way mean that the entire Malay Peninsula was subjected to Portuguese rule.

Instead of exerting total control over the Strait of Malacca, the Portuguese had to face two other Malay powers claiming the Strait namely the Sultanate of Aceh in the northern tip of Sumatra and Johor, at the southern end of the Malay Peninsula. This has caused a tripartite struggle for supremacy in the region between these three political entities for more than a century and none emerged as an absolute victor (Pearn, 1965).

\subsection{The Dutch}

Johor took advantage of the arrival of the Dutch to eject Portuguese from Malacca and revive its influence as the Malay overlord in the region (Hall, 1960). Subsequently, these two powers worked together and in 1641, the Portuguese were ousted permanently from the region, leaving them with East Timor as their only settlement in Southeast Asia (Rusli, 2015). Although the Dutch gained control of Malacca in 1641, however, like the Portuguese, Dutch forces were not able to subject the entire Malay Peninsula under its influence.

Prior to the occupation of Malacca, the Dutch had earlier established a trading post in Bantam, East Java (Harrison, 1966). The Dutch maintained friendly diplomatic relationship with Johor and left them to mend their own internal politics as the Dutch were too pre-occupied with trade (Andaya, 1971). As stated by Andaya:

Dutch missions to the various cities on the Johor River and on Riau marveled at the trading activity they found there. Some of the things traded were gold, eaglewood, kelembak, pedro porco, birdsnest, ivory, camphor, tin, rattan, wax, pepper, salt, rice, copper, spiauter, white Chinese silk, porcelain, iron Chinese pans, cloth, red cloth, Japanese gold thread and opium.

Most trading activities during the Dutch colonial rule in Southeast Asia were transported via the Sunda Strait as it was not too far from the Dutch East Indies Company (Vereenigde Oost-Indische Compagnie) headquarters of Batavia on the island of Java (Pearn, 1965). From a port of global importance in the fifteenth century, Malacca fell from grace in the eighteenth century eclipsed in importance to the more modern and eminent Port of Batavia (Harrison, 1966). The Dutch garnered wealth through the monopoly and exploitation of resources throughout the Malay Archipelago. 


\subsection{The British}

Other than the Portuguese and the Dutch, the British were next to stretch their cloak of dominance over the Malay Archipelago particularly in the Strait of Malacca region. The earliest trading post was in Bengkulu, or alternatively spelt as Bencoolen. Nonetheless, due to its somewhat isolated location, Bencoolen was not generating enough profits. As a result, the British continued hunting for other potential sites to establish their colonies in Southeast Asia (Rusli, Dremliuga and Talaat, 2020).

In 1786, through a treaty entered with Sultan Abdullah Mukaram Shah, the then Sultan of Kedah, the British settled on the island of Penang (Pulau Pinang) straddled at the northern part of the Strait of Malacca (Rusli and Mohamad, 2015). In 1819, the British occupied the island of Singapore (Singapura) ceded by Sultan Hussein of Johor at the southern end of the Malay Peninsula (Marsden, 1966). The Dutch remained midway with its colony of Malacca.

This created a territorial mosaic on the Malay Peninsula that may not be sustainable for the cordial relationships between the British and the Dutch (Rusli, 2016). In order to avoid future disputes, the British and the Dutch entered into the Anglo-Dutch Treaty of London in 1824 (Parry, 1969). Based on the provisions of Article 10 of this treaty, the Dutch relinquished Malacca (Note 1) and the entire Malay Peninsula to the British. In return the British would not dominate Sumatra and islands south of Singapore. (Note 2) Figure 1 displays the spheres of influence of the British and Dutch over the Strait of Malacca region:

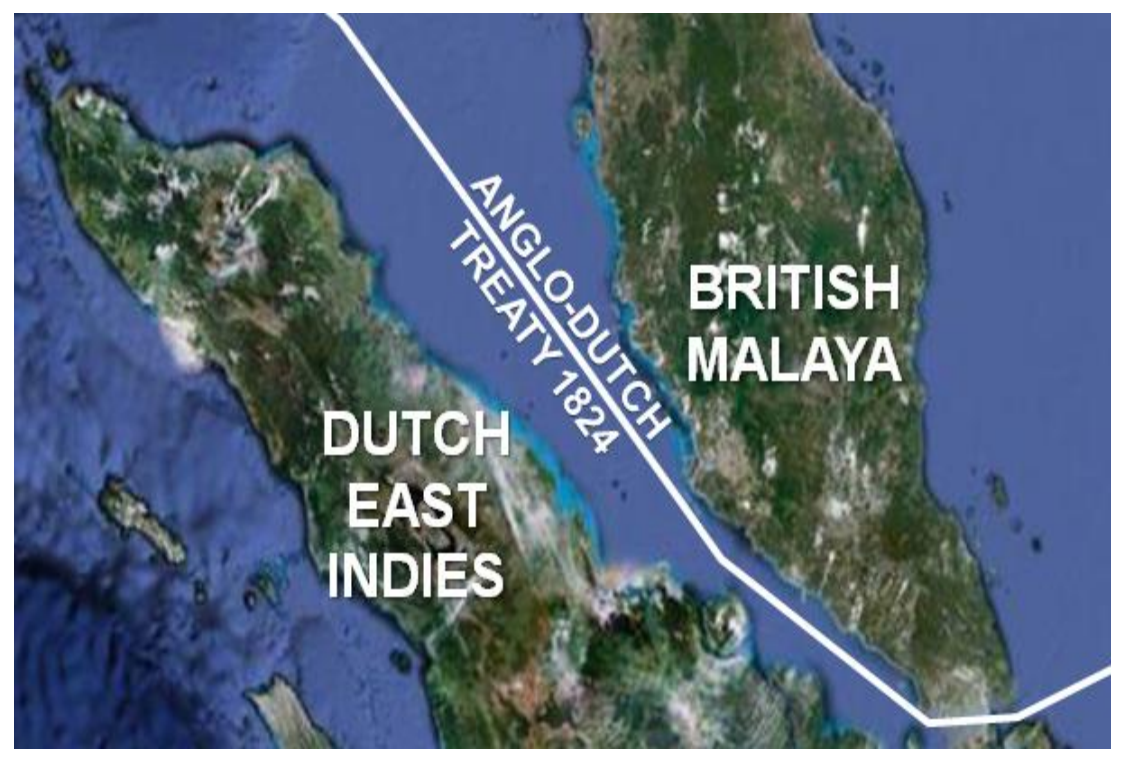

Figure 1. The Effect of Anglo-Dutch Treaty of 1824 (Note 3)

Source: Modified from Google Maps

This arrangement empowered the Dutch to exert their authority over the island of Sumatra and made it possible the British to expand their cloak of influence over the Malay Peninsula without hindrance, effectively dividing the Malay World. Rulers of regional kingdoms within the Strait of Malacca region were not consulted in drafting the treaty. The legacy of this treaty remained until today through the birth of the independent nations of Malaysia and Indonesia (Rusli, Dremliuga and Talaat, 2020).

The efforts of the British to establish ports and trading posts in the Straits Settlements of Penang in Penang in 1786, Malacca in 1824 and Singapore in 1819 were not proved in vain, as the Suez Canal was opened for international navigation soon after in 1869 (Rusli, Bautista and Wan Talaat, 2014). The British port of Singapore has benefited significantly from the Suez Canal-Malacca Strait route and became British most priceless possession in the East (M. H. M. Rusli, 2012).

The British was successful in gradually dominating the entire Malay lands of the Peninsula and exercised suzerainty over existing Malay States. The Sultanate of Johor was the final Malay kingdom to be placed under British protection prior to the eruption of World War II in 1941 (Buyers, 2008). Meanwhile the Dutch effectively executed its 
imperialistic ambitions by over-powering native kingdoms located all across the Malay Archipelago. Hence, the Malay Peninsula was known as British Malaya and the Malay Archipelago was identified as Dutch East Indies.

From 1942 to 1945, the Japanese forces briefly occupied Malaysia and Indonesia. The surrender of the Axis marked the beginning of decolonisation where the former Dutch East Indies became Indonesia and the former British Malaya and British Borneo became Malaysia.

\subsection{Independence and Beyond}

Today, Malaysia, Indonesia and Singapore inherited sovereignty and sovereign rights Britain and the Netherlands held over the Straits of Malacca and Singapore during the colonial era (Jae-hyung, 2003).

With hundreds of years of history of trade, power and colonisation, both the Straits of Malacca and Singapore played a crucial role in shaping the character of this region. The political will to spread the cloak of control over the Strait of Malacca has resulted in numerous conflicts and war between the regional and the colonial power, where the latter has proven triumphant (Hall, 1960).

The historical significance of the Strait of Malacca has resulted in Malacca and Georgetown in Penang, two former British Strait Settlements to be designated as World Heritage Sites by the United Nations Educational, Scientific, and Cultural Organization (UNESCO) in 2008. In addition, numerous ancient Malay palaces could be found in settlements on both sides of the Strait indicating the glorious past of Malay rule in this region before it was overshadowed by colonisation (Fee, 2001).

Subsequent to the establishment of the United Nations (UN) in 1945, the imperialistic desires of colonial powers in dominating and exploiting its former colonies have now been replaced by the nationalistic visions of the littoral States particularly Malaysia, Indonesia and Singapore (M. H. M. Rusli, 2012). This has to be respected by all States. Article 2(4) of the United Nations Charter provides:

All Members shall refrain in their international relations from the threat or use of force against the territorial integrity or political independence of any state, or in any other manner inconsistent with the Purposes of the United Nations. (Note 4)

The Straits of Malacca and Singapore remain as significant maritime conduits until today. Three of the busiest ports in the world are located along the length of the Straits of Malacca and Singapore. Malaysia and Indonesia are working towards transforming themselves into renowned maritime States. This could be done if both nations could sustainably develop the Straits by balancing both the importance of international shipping activities with the protection of the marine environment of this world renowned maritime waterway.

\section{Marine Environment}

The marine environment and maritime features along the length of the Straits of Malacca and Singapore are priceless heritage. While some coastal areas possess pristine white sandy beaches, others are made of coral reefs, vast mangrove forest, mudflats, rocky outcrops and other natural attractions (Jagerroos, 2016).

Islands dotting along the Strait of Malacca such as Langkawi, Penang, Pangkor, Besar and Kukup have been important in the development of the tourism industry in Malaysia (M. H. bin M. Rusli, 2012). Furthermore, coastal sandy beaches like those in Port Dickson, Padang Kemunting, Pengkalan Balak, Lumut and Singapore's Sentosa have many natural features and possess sensitive marine environments that could be vulnerable to excessive shipping activities.

Langkawi Island, a popular tourist island in Malaysia is rich in biodiversity and has been declared as one of the Global GEOPARKS in 2007. Langkawi remains as a major tourist destination visited by more than 2 million tourists each year (Malaysia Registers 25.7 Million Tourists in 2015, 2015).

Some areas of the western coast of Peninsula Malaysia possess marine biodiversity which are among the richest, rarest and most diverse in the entire planet (Basiron, Hooi and Zakariah, 2007). The rich mangrove ecosystem in areas like Matang, Kukup Island and Tanjung Piai are important habitats for numerous species of migratory birds, monkeys estuarine crocodiles (Hooi, 2008). As a result, Tanjung Piai, Kukup Island and Sungai Pulai, all of which are in Johor have been designated as one of the world's RAMSAR sites for its importance in wetland conservation.

The following Figure 2 shows the coastal areas along the Strait of Malacca having high cultural, economic, educational and historical importance: 


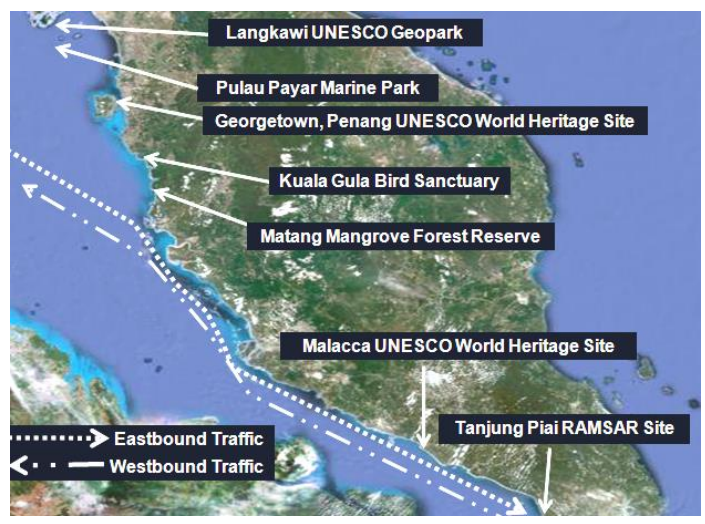

Figure 2. Areas along the Strait of Malacca with high cultural, economic, educational and historical importance Source: Google Maps

Map 2 displays that besides being important for shipping activities, coastal areas particularly along the Malaysian side of the Strait of Malacca are key sites for Marine Parks, UNESCO Geopark, UNESCO World Heritage Sites and RAMSAR sites. Obviously, these are important sites with high cultural, economic, educational and historical importance that must pe protected and preserved from the adverse effects of human-based activities.

\section{Shipping}

It is clear that there are many areas along the length of the Straits of Malacca and Singapore which are rich in biodiversity and needs to be protected and preserved. Nevertheless, in realising the vision for both Malaysia and Indonesia to become world renowned maritime States, both nations have to realise that they have to take part in exploiting maritime trade flowing through the Straits, like their predecessors did. History has narrated that Srivijaya and Malacca became wealthy and powerful due to their success in regulating maritime trade passing through the Straits.

The Straits of Malacca and Singapore form the most viable passageway linking oil producers in the Middle East to the economic powerhouses of East Asia (Hirst, 2014). In 2010, the British Broadcasting Corporation (BBC) News reported that the Straits of Malacca and Singapore accommodate almost six times the volume of transiting traffic traversing the Suez Canal ("Singapore Warns of Threat to Tankers in Malacca Strait," 2010). According to a more recent report issued by Port Klang Vessel Tracking System (VTS), nearly 10 vessels enter or leave the strait every hour, or roughly translate into one vessel every six minutes (Hand, 2018).

In terms of navigational traffic, the Straits of Malacca and Singapore came second only to the Dover Strait, a crucial European chokepoint bordered by the United Kingdom, France and Belgium (Zaideen, 2019). An estimated 15 million barrels of oil pass the Straits of Malacca and Singapore daily (Strait of Malacca Key Chokepoint for Oil Trade, 2018). Vessels transiting the Straits have gradually increased over the past decade as displayed in the following Table 1:

Table 1. Traffic Scenario in the Strait of Malacca

\begin{tabular}{ll}
\hline Year & Number of Traffic \\
\hline 2010 & 74,133 \\
\hline 2011 & 73,538 \\
\hline 2012 & 75,477 \\
\hline 2013 & 77,973 \\
\hline 2014 & 79,344 \\
\hline 2015 & 80,960 \\
\hline 2016 & 83,740 \\
\hline 2017 & 84,456 \\
\hline
\end{tabular}

Source: Marine Department of Peninsular Malaysia 
Statistical data have shown that most of the world's busiest ports are located in East Asian countries including China and South Korea, with Singapore ranked as the busiest, as shown in the following Table 2:

Table 2. World's Top 12 Busiest Ports 2018

\begin{tabular}{llll}
\hline Container Traffic & (TEU- Twenty-Foot Equivalent Units) $\mathbf{2 0 1 8}$ & \\
\hline Rank & Port & Country & TEUs (Million) \\
\hline 1. & Shanghai & China & 42.01 \\
\hline $\mathbf{2 .}$ & Singapore & Singapore & $\mathbf{3 6 . 6 0}$ \\
\hline 3. & Shenzhen & China & 27,74 \\
\hline 4. & Ningbo-Zhoushan & China & 26.35 \\
\hline 5. & Guangzhou & China & 21.87 \\
\hline 6. & Busan & South Korea & 21.66 \\
\hline 7. & Hong Kong & China & 19.60 \\
\hline 8. & Qingdao & China & 18.26 \\
\hline 9. & Tianjin & China & 16.00 \\
\hline 10. & Jebel Ali, Dubai & United Arab Emirates & 14.95 \\
\hline 11. & Rotterdam & Netherlands & 14.51 \\
\hline $\mathbf{1 2}$. & Port Klang & Malaysia & $\mathbf{1 2 . 3 2}$ \\
\hline
\end{tabular}

Source: World Shipping Council

Note: Ports in bold are located along the Straits of Malacca and Singapore

The Straits of Malacca and Singapore have been important in the strategic calculations of nations not only in Southeast Asia but also the surrounding Asia-Pacific region as the main sea lines of communication in this part of the world (Rusli, Dremliuga and Talaat, 2016).

If for any reasons these Straits are not made available for international navigation, shipping companies will have no other choice but to traverse through Indonesian archipelagic straits of Lombok and Makassar, translating into higher shipping costs that may affect the well-being of global economy (Rusli, Bautista and Wan Talaat, 2014). The navigational distance for ships sailing from East to West and vice-versa would be extended by 1000 nautical miles (Song, 2009). The Straits of Malacca and Singapore therefore are crucial for reducing transportation costs (Rusli and Mohamad, 2014).

\section{Protection of the Marine Environment Through Co-operative Mechanism}

Most straits for international navigation all around the world are busy international maritime waterways. Consequently, these Straits are highly exposed to the threats of marine pollution (Rusli, Mustafa and Wan Talaat, 2013).

The issue on compensation to states bordering straits was discussed by the Sea-Bed Committee during the United Nations Conference on the Law of the Sea III (Nordquist, 1993). Considering the significant duties of States bordering straits to maintain aids to navigation in facilitating safe passage, the UK proposed to include a provision that may allow both to co-operate in safeguarding the marine environment of straits.

This proposal from the UK was supported and was inserted into the United Nations Convention on the Law of the Sea 1982 (LOSC) as Article 43, which reads:

User States and States bordering a strait should by agreement cooperate:

(a) in the establishment and maintenance in a strait of necessary navigational and safety aids or other improvements in aid of international navigation; and;

(b) for the prevention, reduction and control of pollution from ships. 
Article 43 of the LOSC seeks to promote the establishment of co-operative measures between user states and states bordering straits in controlling vessel-source pollution and in maintaining the well-being of the marine environment of straits used for international navigation.

The Co-operative Mechanism taking place in the Straits of Malacca and Singapore indicates the success in increasing co-operation between the littoral states and the user states supported by the LOSC itself in Article 43. Be that as it may, this co-operative mechanism was the foremost effort by the international community to put Article 43 of the LOSC into application.

The scope of the Co-operative Mechanism focuses on three components:

(i) A Co-operation Forum for dialogue and discussion;

(ii) A Project Co-ordination Committee (PCC) on the implementation of projects in co-operation with sponsoring users/stakeholders; and

(iii) The Aids to Navigation Fund (the Fund) to receive direct financial contributions for renewal and maintenance of aids to navigation.

The Co-operation Mechanism is receiving constructive feedback from the user states and other interested organisations and stakeholders. Nevertheless, there are arguments that the development of this co-operation has not been consistent with the surge of volume of maritime traffic each year navigating via the Straits of Malacca and Singapore.

While more States have shown interest in projects organised by the PCC, the voluntary monetary contributions received by the Aids to Navigation Fund have not been encouraging (Update on the Aids to Navigation Fund Under the Cooperative Mechanism Between The Littoral States and User States On Safety of Navigation And Environmental Protection In The Straits Of Malacca and Singapore, 2012). To date, Japan remains consistent in constantly contributing financially on a voluntary basis for the maintenance of these critical navigational aids to ensure safety of navigation in the Straits are guaranteed (US\$21mil for navigational aids in Strait of Malacca and Singapore, 2019).

If the present Co-operation Mechanism could no longer sustain and promote sustainable utilisation of the Straits given the steady increase of shipping activities each year, there may be future need for the littoral states to work together in imposing or implementing other prospective measures that go beyond the scope of the international legal framework laid down in the LOSC (Rusli, Dremliuga and Talaat, 2016), such as the proposed designation of the Straits of Malacca and Singapore as Special Areas Under MARPOL 73/78 or Particularly Sensitive Sea Area (Zaideen, 2019).

\section{Conclusion}

The first part of this article discusses the historical significance of the Straits of Malacca and Singapore as strategic sea lines of communication that goes back as early as the third century AD before the region was dominated by Western imperialists. Today these crucial maritime passageways are part of the maritime territory shared by Malaysia, Indonesia, Singapore and a small portion in the north with Thailand.

The second part of this article explains the role of the Straits both in its importance in maritime biodiversity and the shipping industry. The Straits' indispensable role as a maritime superhighway has always been globally acknowledged.

The third part briefly elucidates the importance of the littoral States and the user States to work together in ensuring safe navigation and protection of the marine environment could be sustainably balanced.

As noted by Tarling (1992), 'the success of Srivijaya resulted from Malay nautical skill and organising initiative and of opportunity'. Singapore has been very successful in exploiting its strategic location to develop itself as a global shipping hub. Despite its small size, Singapore today plays a significant role as a crucial fulcrum in maritime trade. As shown in Table 2, the Port of Singapore came second only to Shanghai, handling over 36 million TEUs every year.

Realising the potentials of the Straits of Malacca and Singapore particularly as a global maritime conduit, both Malaysia and Indonesia should develop their oceans policy to go hand in hand with their role as the guardians of the Straits of Malacca and Singapore. Malaysia and Indonesia should strive into becoming two of the world's leading maritime nations, reliving the glorious moments of the bygone Kingdom of Srivijaya and the Sultanate of Malacca in this modern era.

\section{References}

Andaya, L. Y. (1971). The Kingdom of Johor, 1641-1728. Cornell University.

Andaya, L. Y. (2008). Leaves of the same tree: trade and ethnicity in the straits of Melaka. University of Hawai'i Press. https://doi.org/10.1515/9780824863319 
Basiron, M. N., Hooi, T. K., \& Zakariah, Z. M. (2007). Wither Our Ecosystems?. MIMA Bulletin, 14(1), 4.

Buyers, C. (2008). Malacca-Johor: A Brief History.

Dougald, J. W., \& O'Reilly. (2007). Early Civilizations of Southeast Asia. The Rowman \& Littlefield Publishing Group Inc.

Fee, L. K. (2001). The Construction of Malay Identity Across Nations: Malaysia, Singapore and Indonesia. Bidragen tot de Taal-, Land- en Volkenkunde, 157(4), 861-879. https://doi.org/10.1163/22134379-90003795

George, M. (2008). Legal Regime of the Straits of Malacca and Singapore. LexisNexis.

Hall, D. G. E. (1960). A History of South-East Asia (3rd ed.). MacMillan and Company Ltd.

Hand, M. (2018). Exclusive: Malacca Straits VLCC traffic doubles in a decade as shipping traffic hits all time high in 2017, Seatrade Maritime News. Retrieved June 15, 2020, from https://www.seatrade-maritime.com/asia/exclusive-malacca-straits-vlcc-traffic-doubles-decade-shipping-traffichits-all-time-high-2017

Harrison, B. (1966). South-East Asia: A Short History. Macmillan.

Hirst, T. (2014). The world's most important trade route?. World Economic Forum. Retrieved from https://www.weforum.org/agenda/2014/05/world-most-important-trade-route/

Hooi, T. K. (2008). Natural resources exploitation and utilisation. In H. M. Ibrahim, \& H. A. Husin (Eds.), Profile of the straits of Malacca: Malaysia's perspective (p. 75). Maritime Institute of Malaysia.

Ibrahim, H. M., Husin, H. A., \& Sivaguru, D. (2008). The straits of malacca: setting the scene. In H. M. Ibrahim, \& H. A. Husin (Eds.), Profile of the straits of Malacca: Malaysia's perspective (pp. 32-33). Maritime Institute of Malaysia.

Jae-hyung, L. (2003). China and the Asia-Pacific Region. iUniverse, Inc.

Jagerroos, S. (2016). Assessment of Living Resources in the Straits of Malacca, Malaysia: Case Study. Journal of Aquaculture and Marine Biology, 4. https://doi.org/10.15406/jamb.2016.04.00070

Leifer, M. (1978). International Straits of the World, Malacca, Singapore and Indonesia. Sijthoff \& Noordhoff.

Lockard, C. (2009). Southeast Asia in World History. Oxford University Press.

Malaysia Registers 25.7 Million Tourists in 2015. (2015). Tourism Malaysia. Retrieved from http://www.tourism.gov.my/media/view/malaysia-registers-25-7-million-tourists-in-2015

Manguin, P.-Y. (2004). The Archaelogy of Early Maritime Polities of Southeast Asia. In I. Glover, \& P. Bellywood (Eds.), Southeast Asia: from prehistory to history (pp. 294-296). RoutledgeCurzon.

Marsden, W. (1966). The History of Sumatra (3rd ed.). Oxford University Press.

Nordquist, M. H. (1993). United Nations Convention on the Law of the Sea 1982: A Commentary (Volume II). In S. N. Nandan, S. Rosenne, \& N. R. Grandy (Eds.), Second Committee: Articles 1 to 85. Annexes I and II and Final Act, Annex II (pp. 317-320). Martinus Nijhoff.

Parry, C. (1969). Treaty of Commerce and Exchange between Great Britain and the Netherlands, signed at London, 17 March 1824. In The Consolidated Treaty Series (pp. 88-108). Oceana Publications Inc.

Pearn, B. R. (1965). An Introduction to the History of South-East Asia. Longmans.

Rusli, H., Dremliuga, R., \& Talaat, W. (2020). The Anglo-Dutch Treaty 1824: Was the Partitioning of the Malay World Valid?. Journal of East Asia and International Law, XIII(1).

Rusli, H., Dremliuga, R., \& Talaat, W. I. (2016). Legal framework on the marine environment protection of straits used for international navigation: has it been effective in the straits of Malacca and Singapore?. Journal of East Asia and International Law, 9(1), 75-98. https://doi.org/10.14330/jeail.2016.9.1.04

Rusli, M. H. B. M., Mustafa, M. B., \& Wan Talaat, W. I. A. B. (2013). Replacing the transit passage regime with freedom of navigation in the Strait of Malacca: A case study with special reference to the Korea Strait. Ocean and Coastal Management, 78, 25-34. https://doi.org/10.1016/j.ocecoaman.2013.03.003

Rusli, M. H. bin M. (2012). Protecting vital sea lines of communication: A study of the proposed designation of the Straits of Malacca and Singapore as a particularly sensitive sea area. Ocean and Coastal Management, 57, 79-94. https://doi.org/10.1016/j.ocecoaman.2011.12.003

Rusli, M. H. bin M., Bautista, L., \& Wan Talaat, W. I. A. B. (2014). Linking the East and the West: Discovering alternatives to the Straits of Malacca and Singapore. In M. Subhan, S. Yaakub, \& A. B. A. Ghani (Eds.), Port, 
maritime and hinterland development in Southeast Asia (pp. 103-144). Universiti Utara Malaysia.

Rusli, M. H. M. (2012). Straits of Malacca and Singapore: Pride of the Malay Archipelago, Priceless Maritime Heritage of the World. Jurnal Hadhari, 109-127.

Rusli, M. H. M. (2015). Dua Sudut Nusantara: Catatan Dari Kota Dili, mStar Online. Retrieved June 15, 2020, from https://www.mstar.com.my/lain-lain/rencana/2015/05/29/pulau-timor

Rusli, M. H. M. (2016). The Anglo Dutch Treaty 1824: Was the partitioning of the Malay Archipelago Valid?. Astro Awani. Retrieved January 9, 2017, from http://english.astroawani.com/malaysia-news/anglo-dutch-treaty-1824-was-partitioning-malay-world-valid-122 766

Rusli, M. H. M., \& Mohamad, R. (2014). A priceless maritime heritage, new straits times. Retrieved from https://www.nst.com.my/news/2015/09/priceless-maritime-heritage

Rusli, M. H. M., \& Mohamad, R. (2015). To return or not to return Penang to Kedah (p. 52). Focus Malaysia.

Secretariat of the Aids to Navigation Fund. (2012). Update on the aids to navigation fund under the cooperative mechanism between the littoral states and user states on safety of navigation and environmental protection in the straits of Malacca and Singapore. Retrieved from http://www.cm-soms.com/uploads/1/19/6.1\%20Report\%20of\%208th\%20Aids\%20to\%20Navigation\%20Fund\% 20Committee\%20Meeting.pdf

Song, Y. (2009). Regional Maritime Security Initiative (RMSI) and Enhancing Security in the Straits of Malacca: Littoral States and Regional Responses. In S. Wu, \& K. Zou (Eds.), Maritime security in the South China sea: regional implications and international cooperation (p. 84). Ashgate Publishing Ltd.

Strait of Malacca Key Chokepoint for Oil Trade. (2018). The Maritime Executive. Retrieved from https://www.maritime-executive.com/article/strait-of-malacca-key-chokepoint-for-oil-trade

Tarling, N. (1992). The Cambridge History of Southeast Asia: From Early Times to c. 1800. Cambridge University Press. https://doi.org/10.1017/CHOL9780521355063

US\$21mil for navigational aids in Strait of Malacca and Singapore. (2019). The Star. Retrieved from https://www.thestar.com.my/news/nation/2019/09/30/us21mil-for-navigational-aids-in-strait-of-malacca--and-si ngapore

Williams, L. E. (1976). Southeast Asia: A history. Oxford University Press.

Zaideen, I. M. M. (2019). Should the Straits of Malacca and Singapore Be Designated as Special Area?. Environmental Policy and Law, 49(4-5), 236-240. https://doi.org/10.3233/EPL-190160

Zulkifli, N., et al.. (2020). Maritime Cooperation in the Straits of Malacca (2016-2020): Challenges and Recommend For a New Framework. Asian Journal of Research in Education and Social Sciences, 2(2).

\section{Notes}

Note 1. Article 10 of the Anglo-Dutch Treaty 1824 states 'The Town and Fort of Malacca, ceded to His Britannick Majesty, and His Netherland Majesty engages for himself and his subjects never to form any establishment in any part of Peninsular of Malacca'.

Note 2. Article 9 of the Anglo-Dutch Treaty reads 'The Factory of Fort Malborough, and all the English Possesion in Sumatra, ceded to His Netherland Majesty.'

Note 3. Note: The line does not represent the exact boundary demarcation line between the two territories as this is just a matter of illustration only.

Note 4. United Nations, Charter of the United Nations (1985) United Nations $<$ http://www.un.org/en/documents/charter/chapter1.shtml>.

\section{Copyrights}

Copyright for this article is retained by the author(s), with first publication rights granted to the journal.

This is an open-access article distributed under the terms and conditions of the Creative Commons Attribution license (http://creativecommons.org/licenses/by/4.0/). 